\title{
Investigation of a healthcare-associated candida infections in a Turkish intensive care unit: risk factors, therapy and clinical outcome
}

\author{
Fatma Avcioglu $^{1}$ - Fatma Sirmatel ${ }^{2}$ - Mustafa Behcet ${ }^{1} \cdot$ Ogulcan Ozarslan $^{2} \cdot$ Hasan Tahsin \\ Gozdas $^{2}$ \\ ${ }^{I}$ Department of Medical Microbiology, Faculty of Medicine, Bolu Abant Izzet Baysal University, Bolu, Turkey \\ ${ }^{2}$ Department of Infectious Diseases and Clinical Microbiology, Faculty of Medicine, Bolu Abant Izzet Baysal University, \\ Bolu, Turkey
}

\section{ABSTRACT}

Aim: Candida infections develop especially in intensive care unit (ICU) patients and increase the mortality rates. So, early and accurate diagnosis of Candida infections and determination of risk factors are very important. We aimed to retrospectively investigate Candida infections in terms of species and risk factors for candidemia caused by fungi.

Methods: Candida infections in critically ill patients hospitalized in the Intensive Care Unit of Bolu Abant Izzet Baysal University Training and Research Hospital between January 2014 and December 2018 were retrospectively analyzed. The isolated Candida species were evaluated according to the sample types. The cases were investigated in terms of mortality due to candidiasis, previously used antibiotics and isolated Candida species.

Results: 34 Candida species isolated from fungal cultures in ICUs were included in the study. Candida albicans (73.5\%) was the most prevalent species isolated (NAC 26.5\%). Patients with Candida isolated in their urine samples $(76 \%)$ had a higher mortality rate than patients with Candida from other regions.

Conclusion: The results of our study suggest that the highest rate of candidiasis (88\%) is in patients who received beta-lactam antibiotic treatment. In addition, we think that when Candida species are detected in the urine samples of critically ill patients in the ICU, care should be taken in terms of candidiasis.

Keywords: Candida, health care, intensive care unit, candidiasis, mortality.

Dr. Fatma Avcioglu,

Department of Medical Microbiology, Bolu Abant Izzet Baysal University, Faculty of Medicine, Bolu, Turkey

E-mail: fatmaavcioglu@yahoo.com.tr

Received: 2020-08-10 / Revised: 2020-08-27

Accepted: 2020-09-13 / Published online: 2021-01-01

\section{Introduction}

Healthcare-associated infections (HAIs) are the infections that occur while receiving healthcare, that are developed in a hospital or another health center. These infections are seen within the first 48 hours or in longer period after hospitalization or that occur within 30 days after receiving healthcare. Center for Disease Control and Prevention (CDC) reported that 1.7 million hospitalized patients acquire HAIs every year while receiving a treatment for other health problems and more than 98.000 patients (one out of 17) die annually due to HAIs [1]. Candida species are opportunistic pathogenic microorganisms that are normally seen in human flora and may be the cause of an infection when the host's immune system weakens [2]. As a result of improving 
healthcare services, many diseases are no longer a threat to people and their life expectancy is prolonged. However, various opportunistic infections occur due to prolonged hospital stays and antibiotics used. With the increase of awareness, the number of reported opportunistic fungal infections started to increase. In HAIs, besides patient-related factors, procedures applied to patients, longterm antibiotic use and candida colonization cause invasive candida infections with high mortality [3]. Candida species are the fourth most common pathogens causing nosocomial bloodstream infections [4]. The incidence of both Candida albicans (C. albicans) and nonalbicans Candida (NAC) species is increasing [5]. Determination of risk factors in patients with Candida infections will be useful for the prevention of mortality and morbidity in the future. Hence, this study aimed to determine risk factors for candida infections due to $C$. albicans and NAC species and compare the patients infected by these two species.

\section{Materials and Methods}

The study protocol was approved by the Bolu Abant İzzet Baysal University Research Ethics Committee (Date and decision number: 2019/237). After getting approval from the local ethics committee, we retrospectively investigated candida infections in critically ill (A patient who needs monitoring to live because of organ/system failures or dysfunction) intensive care unit (ICU) patients in our institution between January 2014 and December 2018. Candida isolates were obtained from different clinical specimens such as urine, blood, sputum, wound, pleural fluid, and peritoneal fluid. Diagnosis of HAI candidiasis infection was made according to CDC criteria [6]. Only the first episode of candidiasis was considered in each patient, recurrent episodes were excluded. Patients were followed up by an infectious diseases specialist and infection control nurse of our hospital on daily basis and required antibiotic and antifungal treatments were managed according to the guidelines.

\section{Microbiologic sample identification}

Samples sent to our microbiology laboratory were cultivated into Sabouraud Dextrose Agar (SDA) (Oxoid, England) medium and incubated at $37^{\circ} \mathrm{C}$ for $24-48$ hours. After incubation, yeast isolates in which growth was found were identified at the level of species by using germ tube test and VITEK 2 Compact (BioMérieux, France) fully automated identification system.

Isolated candida species were evaluated according to the sample types. Cases were statistically compared in terms of mortality, previously used antibiotics and isolated candida species. Results were shown as the mean \pm standard deviation for continuous variables, and the number of cases and percentage (\%) for nominal variables. Categorical variables were evaluated using Pearson's Chi-square test and Fisher's exact test. Differences were considered statistically significant if the $\mathrm{P}$ value was less than 0.05 .

\section{Results}

A total of 34 candida species were isolated from fungal cultures of 34 patients ( 19 female and 15 male). Cultures were obtained from different clinical specimens. Among the isolates, 25 were C. albicans and 9 were NAC species. 17 isolates were from blood samples, 13 from urine samples and 4 from other types of samples (pleural fluid, peritoneal fluid, wound and sputum). When isolated candida strains were distinguished as $C$. albicans and NAC, the highest rate of mortality was seen in patients in 
whom $C$. albicans was isolated. When the clinical course of the patients was evaluated in terms of discharge and mortality, the highest mortality rate was found in patients in whom $C$. albicans were isolated from their urine samples. Mortality rates according to sample types of $C$. albicans and NAC were also given in Table 1.
When the patients were classified according to the antibiotics (Beta-lactam, Carbapenem, Quinolone, anti-anaerobic antibiotics, etc.) they used before $C$. albicans and NAC were isolated, the highest rate of candidiasis $(88 \%)$ was seen in patients who received beta-lactam antibiotic treatment (Table 2).

Table 1. Previously used antibiotics of the cases.

\begin{tabular}{|l|l|l|l|l|}
\hline Antibiotics & Male (n/\%) & Female (n/\%) & Total (n/\%) & $P$ \\
\hline Beta Lactam & $17 / 89.50$ & $13 / 86.70$ & $30 / 88.20$ & 0.801 \\
\hline Carbapenem & $3 / 15.80$ & $4 / 26.70$ & $7 / 20.60$ & 0.436 \\
\hline Quinolone & $5 / 26.30$ & $3 / 20$ & $8 / 23.50$ & 0.666 \\
\hline Anti-anaerobic & $3 / 15.80$ & $2 / 13.30$ & $5 / 14.70$ & 0.841 \\
\hline Anti-staphylococcal & $3 / 15.80$ & $5 / 33.30$ & $8 / 23.50$ & 0.231 \\
\hline Other & $6 / 31.60$ & $3 / 20$ & $9 / 26.50$ & 0.447 \\
\hline
\end{tabular}

Table 2. Discharge and mortality rates of the cases according to culture type.

\begin{tabular}{|c|c|c|c|c|c|c|}
\hline \multirow{3}{*}{ Culture type } & \multicolumn{4}{|l|}{ Pathogen } & \multirow{2}{*}{\multicolumn{2}{|c|}{ Total (n/\%) }} \\
\hline & \multicolumn{2}{|c|}{ Candida albicans (n/\%) } & \multicolumn{2}{|c|}{$\begin{array}{l}\text { Non-albicans Candida } \\
(\mathrm{n} / \%)\end{array}$} & & \\
\hline & Discharge & Exitus & Discharge & Exitus & Discharge & Exitus \\
\hline Urine & $3 / 30$ & $7 / 70$ & $0 / 0$ & $3 / 100$ & $3 / 23.10$ & $10 / 76.90$ \\
\hline Blood & $8 / 61.50$ & $5 / 38.5$ & $1 / 25$ & $3 / 75$ & $9 / 52.90$ & $8 / 47.10$ \\
\hline Sputum & $0 / 0$ & $0 / 0$ & $1 / 100$ & $0 / 0$ & $1 / 100$ & $0 / 0$ \\
\hline Wound & $1 / 100$ & $0 / 0$ & $0 / 0$ & $0 / 0$ & $1 / 100$ & $0 / 0$ \\
\hline Pleural Fluid & $0 / 0$ & $0 / 0$ & $0 / 0$ & $1 / 100$ & $0 / 0$ & $1 / 100$ \\
\hline $\begin{array}{l}\text { Peritoneal } \\
\text { Fluid }\end{array}$ & $1 / 100$ & $0 / 0$ & $0 / 0$ & $0 / 0$ & $1 / 100$ & $0 / 0$ \\
\hline Total & $13 / 52$ & $12 / 48$ & $2 / 22.20$ & $7 / 77.80$ & $15 / 44.10$ & $19 / 55.90$ \\
\hline$p$ & 0.235 & & 0.198 & & & \\
\hline
\end{tabular}




\section{Discussion}

Candida infections are important health problems in critically ill patients in ICUs. These infections occur as a result of complicated surgical procedures, use of invasive medical devices and long term and broad-spectrum antibiotic treatment [5]. Thus, determining the risk factors for Candida infections will contribute to the decrease in occurrence of these types of infections. Recently, distribution of Candida species has shown an increase in favour of NAC rather than C. albicans [7]. Less response to antifungal treatment in NAC infections contribute to the increase in mortality rates [8-10]. In studies conducted in Turkey, $C$. albicans (CA) was generally isolated more often and the incidence rates of CA differs between $45.8 \%$ and $75.6 \%$ (Table 3) [11-16].
In this study, the rate of CA among isolated Candida infections that were found in critically ill ICU patients was $73.5 \%$. In our study, we also found the incidence of $\mathrm{CA}$ infections to be more than NAC infections. Compared with other studies, it was thought that the limited number of patient groups included in this study (critically ill) may lead to a higher incidence of CA.

Candida infections are more commonly seen in patients hospitalized in ICUs due to many different reasons and also because of their weak immune system. In these kinds of patients, interventional procedures such as urinary catheter and intravenous catheter applications increase the susceptibility of patients against these infections. Candida infections are

Table 3. Previous studies of health care associated candidiasis infections from Turkey.

\begin{tabular}{|c|c|c|c|c|}
\hline Studies & Institution & Subjects & Duration & Result \\
\hline Çagan et al. ${ }^{11}$ & $\begin{array}{l}\text { Marmara University } \\
\text { Faculty of Medicine }\end{array}$ & $\begin{array}{l}29 \text { pediatric } \\
\text { patients }\end{array}$ & 2011-2013 & $\begin{array}{l}55.1 \% C . \\
\text { albicans }\end{array}$ \\
\hline Karalti $^{12}$ & $\begin{array}{l}\text { Yeditepe University } \\
\text { Hospital }\end{array}$ & $\begin{array}{l}249 \text { urine } \\
\text { specimen }\end{array}$ & $2006-2016$ & $\begin{array}{l}54.2 \% C \text {. } \\
\text { albicans }\end{array}$ \\
\hline Kilincel et al. ${ }^{13}$ & $\begin{array}{l}\text { Duzce University, } \\
\text { Research and Training } \\
\text { Hospital }\end{array}$ & $\begin{array}{l}81 \text { blood } \\
\text { cultures }\end{array}$ & $2012-2018$ & $\begin{array}{l}55 \% C . \\
\text { albicans }\end{array}$ \\
\hline Savci et al. ${ }^{14}$ & $\begin{array}{l}\text { Bozok University Research } \\
\text { and Application Hospital }\end{array}$ & $\begin{array}{l}42 \text { clinical } \\
\text { specimens }\end{array}$ & $2014-2016$ & $\begin{array}{l}66.7 \% \text { C. } \\
\text { albicans }\end{array}$ \\
\hline Yapar et al. ${ }^{15}$ & $\begin{array}{l}\text { Tertiary-care educational } \\
\text { hospitals in Turkey }\end{array}$ & $\begin{array}{l}83 \text { Blood } \\
\text { cultures }\end{array}$ & $2008-2009$ & $\begin{array}{l}45.8 \% C \\
\text { albicans }\end{array}$ \\
\hline Sav et al. ${ }^{16}$ & $\begin{array}{l}\text { Erciyes University } \\
\text { Hospital }\end{array}$ & $\begin{array}{l}3905 \text { clinical } \\
\text { specimens }\end{array}$ & 2011-2012 & $\begin{array}{l}75.6 \% C . \\
\text { albicans }\end{array}$ \\
\hline Present study & $\begin{array}{l}\text { Bolu Abant İzzet Baysal } \\
\text { University Hospital }\end{array}$ & $\begin{array}{l}34 \text { critically ill } \\
\text { patients }\end{array}$ & $2014-2018$ & $\begin{array}{l}73.5 \% C \text {. } \\
\text { albicans }\end{array}$ \\
\hline
\end{tabular}


characterized with high rate of mortality [17]. The most common types of infections seen in ICUs are bloodstream infections, catheterassociated infections and urinary tract infections [18]. In this study, the highest rate of Candida was isolated from blood (50\%) and urine $(38 \%)$ samples. Mortality rate was higher in patients in whom candida was isolated from urine samples $(76 \%)$ compared to the patients in whom candida was isolated from other sites. It should be considered that Candida isolated especially from urine samples of critically ill patients in ICUs may increase mortality.

Multiple risk factors were attributed to Candida infections. One of the most important predisposing factors is long-term and broadspectrum antibiotic treatment [19]. In this study, when the patients were classified according to the types of antibiotics used before the detection of Candida infection, beta lactam antibiotics (88.2\%) was found to be the most commonly used antibiotic group. Studies on the predisposing factors causing Candida infections are not sufficient in Turkey. However, Yapar et al. [15] and Büyüktuna et al. [19], revealed a relationship between long term antibiotic use and Candida infection.

Our study has some limitations. Patients in ICUs who were included in the study were only analyzed according to the types of antibiotics used in terms of predisposing factors. Predisposing conditions such as hematopoietic stem sell or solid organ transplantation, diabetes mellitus, malignancy, trauma and renal failure were not questioned in patients. Moreover, the presence of urinary catheter and intravenous catheter was not investigated. In addition, several factors other than candida infection might have contributed to mortality. Therefore, we cannot definitely say that Candida infections were the only reason of mortality rates.
In conclusion, it was concluded in this study that the highest rate of Candida infections in ICU patients belonged to C. albicans species. It should be considered that Candida species isolated from candida infections may affect the prognosis of patients. Early diagnosis and treatment in Candida infections will help to decrease mortality rates. In this study, the highest rate of mortality was seen in C. albicans infections strains isolated from urine samples. Therefore, we think that when Candida species are detected in the urine samples of critically ill patients in the ICU, care should be taken in terms of candidiasis.

\section{Acknowledgement}

This study was presented as an oral presentation in "Turkey 7th International EKMUD Congress 8-13 May 2018"

Funding: There is no financial support and sponsorship

Conflict of Interest: The authors declare that they have no conflict of interest.

Ethical statement: The study was conducted in accordance with the ethical approval of the University Ethics Committee (Date and decision number: 2019/237).

ORCID iD of the author(s)

Fatma Avcioglu / 0000-0002-6011-7775

Fatma Sirmatel / 0000-0003-0442-5981

Mustafa Behcet / 0000-0002-5676-6983

Ogulcan Ozarslan / 0000-0002-2635-7011

Hasan Tahsin Gozdas / 0000-0003-3857-685X

Copyrights: (C) 2021@author (s).

This is an open access article distributed under the terms of the Creative Commons Attribution License (CC BY 4.0), which permits unrestricted use, distribution, and reproduction in any medium, provided the original author(s) 
and source are credited and that the original publication in this journal is cited, in accordance with accepted academic practice. No use, distribution or reproduction is permitted which does not comply with these terms.

\section{References}

[1]Haque M, Sartelli M, McKimm J, et al. Health care-associated infections - an overview. Infect Drug Resist. 2018;1:232133.

[2]Yiş R, Doluca M. Identification of Candida species by restriction enzyme analysis. Turk J Med Sci. 2018;48(5):1058-67.

[3] Yapar N. Epidemiology and risk factors for invasive candidiasis. Ther Clin Risk Manag. 2014; 10:95-105.

[4]Atici S, Soysal A, Kepenekli Kadayifci E, et al. Healthcare-associated infections in a newly opened pediatric intensive care unit in Turkey: Results of four-year surveillance. J Infect Dev Ctries. 2016;10(3):254-59.

[5]Montagna MT, Lovero G, Borghi E, et al. Candidemia in intensive care unit: a nationwide prospective observational survey (GISIA-3 study) and review of the European literature from 2000 through 2013. Eur Rev Med Pharmacol Sci. 2014;18(5):661-74.

[6]Horan TC, Andrus M, Dudeck MA. CDC/NHSN surveillance definition of health care-associated infection and criteria for specific types of infections in the acute care setting. Am J Infect Control. 2008;36(5):309-32.

[7]Al-Dorzi HM, Sakkijha H, Khan R, et al. Invasive candidiasis in critically 11 patients: a prospective cohort study in two tertiary care centers. J Intensive Care Med. 2020;35(6):542-53.

[8]Krcmery V, Barnes AJ. Non-albicans Candida spp. causing fungaemia: pathogenicity and antifungal resistance. J Hosp Infect. 2002;50(4):243-60.

[9] Alişkan HE, Bozkirli ED, Çolakoğlu Ş, et al. Evaluation of risk factors in candidemias caused by Candida albicans and nonalbicans Candida species, isolated from the blood cultures for three years period in our hospital. Turk Hij ve Deney Biyol Derg. 2016;73(1):15-24.

[10]Erdem F, Tuncer Ertem G, Oral B, et al. Epidemiological and microbiological evaluation of nosocomial infections caused by Candida species. Mikrobiyol Bul. 2012;46(4):637-48.

[11] Çağan E, Soysal A, Bakır M. Childhood candida infections: single center experience. Cukurova Med J. 2015;40(2):245-51.

[12]Karaltı İ. Retrospective evaluation of candida species isolated from urine in a university hospital. The Journal of Fungus. 2018;9(1):76-79.

[13] Kılınçel Ö, Akar N, Karamurat ZD, et al. Distribution and antifungal susceptibility of candida species isolated from blood cultures. Türk Mikrobiyoloji Cem Derg. 2018;48(4):256-63.

[14] Savc1 Ü, Y1lmaz N. Distribution of Candida species isolated from various sample and antifungal resistance ratio. Turk J Clin Lab. 2017;8(3):85-90.

[15] Yapar N, Pullukcu H, Avkan-Oguz V, et al. Evaluation of species distribution and risk factors of candidemia: a multicenter casecontrol study. Med Mycol. 2011;49(1):2631 .

[16] Sav H, Demir G, Atalay MA, et al. Evaluation of Candida strains isolated from clinical specimens. Turk Hij Den Biyol Derg. 2013;70(4):175-80.

[17]Pelit S, Uzun M. Investigation of species distribution and antifungal susceptibility of candida species isolated from various 
clinical samples from intensive care unit patients. Journal of Medical and Surgical Intensive Care Medicine. 2016;7(2):49-52.

[18] Jahagirdar VL, Davane MS, Aradhye SC, et al. Candida species as potential nosocomial pathogens - A review. Electron J Gen Med. 2018;15(2):em05.

[19]Büyüktuna SA, Hasbek M, Elaldı N, et al. Epidemiological analysis of Nosocomial Candida infections: Experience of a university hospital. Cumhur Med J. 2019;41(2):318-27. 